\title{
Interrogative "complements" and question design in Estonian
}

Leelo Keevallik

\section{Book Chapter}

Cite this book chapter as:

Keevallik, L. Interrogative "complements" and question design in Estonian, In 'Subordination' in Conversation: A Cross-Linguistic Perspective, Ritva Laury \& Ryoko Suzuki (eds), J ohn Benjamins Publishing Company; 2011, pp. 37-68. ISBN: 9789027226341,9789027286963

Series: Studies in Language and Social Interaction, ISSN: 1879-3983, No. 24

Copyright: J ohn Benjamins Publishing Company

The self-archived postprint version of this conference article is available at Linköping University Institutional Repository (DiVA):

http://urn.kb.se/ resolve?urn=urn:nbn:se:liu:diva-103107 


\section{John Benjamins Publishing Company}

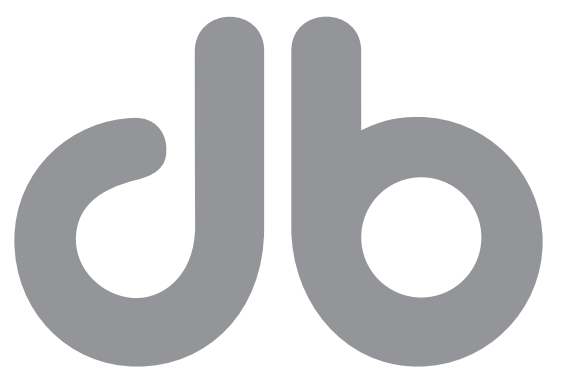

This is a contribution from Subordination in Conversation. A cross-linguistic perspective. Edited by Ritva Laury and Ryoko Suzuki.

๑) 2011. John Benjamins Publishing Company

This electronic file may not be altered in any way.

The author(s) of this article is/are permitted to use this PDF file to generate printed copies to be used by way of offprints, for their personal use only.

Permission is granted by the publishers to post this file on a closed server which is accessible to members (students and staff) only of the author's/s' institute, it is not permitted to post this PDF on the open internet.

For any other use of this material prior written permission should be obtained from the publishers or through the Copyright Clearance Center (for USA: www.copyright.com). Please contact rights@benjamins.nl or consult our website: www.benjamins.com Tables of Contents, abstracts and guidelines are available at www.benjamins.com 


\title{
Interrogative "complements" and question design in Estonian
}

\author{
Leelo Keevallik \\ Research Associate, Uppsala University
}

\begin{abstract}
Some interrogative subject and object complement clauses are not treated as subordinate in Estonian interaction. They are interactionally profiled, as participants answer them as questions. Grammatically, they behave like independent clauses, displaying inversion and the turn-final question particle $v \ddot{a} / v e$. The main clauses considered in the chapter, ütle/öelge 'say!', rä̈gi 'talk/tell!', ei tea 'not know', and uvitav 'interesting', instead function as (epistemic) particles projecting and designing questions in a sequentially and interpersonally sensitive way.
\end{abstract}

Keywords: interrogative complements, indirect questions, interaction, epistemics, pragmatic particles

\section{Introduction}

Grammar comes into being in the everyday usage of language. It is created, negotiated, and changed in encounters between the speakers of the language (Bybee \& Hopper 2001, Hopper 1987, 1998, Schegloff 1996). When engaging in conversation, participants analyze each others' contributions and regularly display their understanding of what was said in subsequent turns at talk. These displayed understandings are available to the analyst, who by focusing on sequences of turns can make empirically based claims on how the speakers in a certain language community deploy and interpret different grammatical devices. This proof procedure has been established as one of the cornerstones of conversation analysis (Sacks, Schegloff \& Jefferson 1974: 728-729). Studying the core grammatical structures, such as clause combining and complementation, in interaction is therefore a great opportunity as well as a necessity for an adequate description of a language.

The aim of this study is to look at how speakers of Estonian use clauses that have been analyzed as interrogative complements in Estonian grammar and as indirect questions in some other traditions (e.g. Payne 1997: 316). The clauses start 
with interrogative pronouns or question particles, and they have been described as dependent clauses that follow complement taking predicates (CTPs) or as predicate adjective clauses (Erelt et al. 1993: 107-108; 289-291). The paper focuses on three prototypical CTPs, namely verbs of speaking and knowing, and one adjective. The choice is made purely on the basis of frequency, as these were the only recurrent formats of the relevant kind in the data. The three CTPs are ïtle/öelge, the imperative of 'say', rä̈gi, the imperative of 'tell/talk', and (ei) tea '(NEG) know'; the predicate adjective is uvitav 'interesting'.

In interactional Estonian all the four items are regularly used together with interrogative clauses. The paper argues that these interrogative clauses are not treated as subordinate complements by the speakers of Estonian, i.e. they are not cognitively, interactionally or prosodically backgrounded, or grammatically dependent. They do not display any syntactic features that would make them incapable to stand in isolation, as they involve finite verb forms and do not involve subordinate conjunctions. Instead, the clauses function as independent clauses, while the "main clauses" are used as epistemic particles and devices of structuring conversation. Their contribution is content-wise subsidiary and at a different structural level in comparison with what the interrogative clause accomplishes. There is only one process that is cognitively profiled (Langacker 1991) in the compound syntactic unit, and that is expressed in the interrogative clause. All of the formats are implemented in the social action that can most generally be characterized as asking a question. The paper will take a systematic look on question design that involves these short "main clauses" and "complements".

A number of recent studies have questioned the existence of complementation in different languages (Englebretson 2003, Laury 2006, Thompson 2002, Thompson and Mulac 1991). The speakers in actual conversations have been shown to treat the CTP clauses as evidential/epistemic/evaluative phrases that modify the upcoming clause (Thompson 2002). Therefore, the CTP clauses cannot be analyzed as being main clauses in regard to the complements. In contrast to the CTPs that have been described in the literature so far, the imperatives studied in the current paper relate to turn-taking and conversation structure rather than modify the upcoming interrogative clause. The paper thus contributes to the literature on reanalyzing the relationship between complements and main clauses, but brings in a new dimension of sequencing of actions as a crucial factor in understanding the functions of the "main clauses". Second, it will argue that the CTPs attend to the assumed epistemic state of the conversation partner, thus working on the intersubjective level rather than phrasing the subjective attitude of the speaker.

It is customary to analyze the following sentences as including a main or matrix clause and an interrogative complement clause (Erelt et al. 1993: 281-282, 289-292). The idiomatic English translations of the CTPs are best approximations 
but since there is no word-by-word counterpart to any of these items, they will be left untranslated in the rest of the article. Transcription and glossing conventions can be found at the end of the article.

(1) Ütle mis ma tegema pean.

say;IMP;2sG what I do:suP must:1sG

'Tell me what I have to do'

(2) Räägi kuidas sul läks täna. tell;IMP;2SG how you:ADs go:IMF;3sG today

'Tell me how it went today'

(3) Ei tea mis kellast doktor Laane vastu võtab. NEG know what time:ELT doctor NAME receive:3sG 'I wonder when doctor Laane will be seeing patients'

(4) Uvitav miks ma talle meeldin. interesting why I she:ALL please:1sG 'I wonder why she likes me.'

In cases (1-3), the verb is transitive, needing an object, and the following clause is thus analyzed as an object complement clause. In Example (4) the adjective (possibly an elliptical predicate adjective clause) is followed by a subject complement clause. The traditional analysis is as follows.

Main clause

Ütle 'tell me'

Räägi 'tell me'

Ei tea 'I wonder'

Uvitav 'I wonder'
Object or subject complement mis ma tegema pean 'what I have to do' kuidas sul läks täna 'how it went today' mis kellast doctor Laane vastu võtab 'when doctor Laane will be seeing patients' miks ma talle meeldin 'why she likes me'

Using interactional data, the paper discusses the semantic, syntactic and prosodic features of these short 'main clauses' in relation to the following interrogative clauses. The first question is, which part is profiled by the participants in terms of the achieved action. And the second one, related and no less crucial, is how the two parts figure in the interactive tasks of turn construction, sequence organization and interpersonal epistemics.

\section{The data}

The data comes mainly from two contemporary spoken language corpora. The first one was collected and transcribed by myself in 1997-1998 and consists of 
naturally occurring telemarketing calls as well as everyday calls between family members, relatives, friends, and colleagues (henceforth the LK corpus). It includes about 103, 000 words. The Tartu corpus is publicly available and constantly growing, consisting of about 700, 000 words at the moment. The data there comes from a variety of settings, including face-to-face conversations (henceforth the TA corpus). Internet has been used as a supplementary source. It is nowadays the largest collection of informal and interactional Estonian. My own native speaker intuition has provided the guarantee that the examples from there are indeed idiomatic. Each example is provided with a code showing its origin (LK, TA, NET respectively).

Hundreds of relevant examples can of course be found on the internet. However, the analysis here depends on a close study of the evolving interactional sequences, as the immediate reaction to the format by another participant is crucial. The main weight of the analysis is therefore on the conversational data.

As can be seen in Table (1), there are two imperative forms to take into account, as number is marked in verbs in Estonian. The singular forms are ütle and räägi, and the plural ones öelge (with a morphological variant ütelge which occurs four times in TA) and rääkige. The latter does not occur with interrogative clauses in the corpora due to contextual differences discussed below. The choice between singular and plural may depend on the number of recipients. More often, though, the forms are chosen according to social distance between the speakers and the formality of the situation. Plural implies distance and deference. In negation, however, Estonian verb forms take neither person nor number endings, which is why ei tea can be applied to any person or number.

The numbers in the table show that out of the three CTPs the imperative plural of 'say' is most often used with interrogative clauses and the imperative of 'tell, talk' is least frequent in this collocation. Qualitatively, however, they work in a similar way. We will first look at these two verbs when followed by an interrogative clause.

Table 1. General frequencies of the items in the spoken language corpora

\begin{tabular}{lccc}
\hline & LK & TA & Total \\
\hline ütle 'say!' & 16 & 22 & 38 \\
öelge 'say:PL!' & 50 & $55+4$ (ütelge) & 109 \\
räägi 'tell!' & 10 & 13 & 23 \\
rääkige 'tell:PL!' & 0 & 0 & 0 \\
(ei) tea '(NEG) know' & 13 & 25 & 38 \\
uvitav 'interesting' & 4 & 17 & 21 \\
\hline
\end{tabular}




\section{Projecting actions 1: The imperative of 'say'}

A typical example of ütle/öelge comes from the very beginning of a telephone call. In Example (5) the caller inquires about when a person will arrive at his job. The inquiry, which also represents the reason for the call, is preceded by öelge. In this particular sequential environment, öelge alone cannot constitute a complete turn, as it does not "recognizably implement an action" (Schegloff 1996: 59). It is pragmatically incomplete and therefore heard by the participants as projecting additional talk. The next speaker is expected to wait until the projected unit, a question, has been produced.

Throughout the examples of the paper, the "main clause" will be bolded and the "complement clause" italicized.

(5) $1 \mathrm{~K}$ : rahvamuuseum, Mirja Kaarep kuuleb,

folk.museum NAME NAME listen:3sG

'Folk museum, Mirja Kaarep here.'

2 I: tervist.

'Hi!'

$3 \mathrm{~K}$ : tervist,

'Hi!'

$4 \mathrm{I}$ : palun öelge (0.8) mis kell: omme Siivelt please tell:IMP;2PL what time tomorrow NAME 'Please öelge (0.8) at what time will Siivelt'

5 Alo tööle tuleb.

NAME work:ALL come:3sG

'Alo arrive at work tomorrow.'

$6 \mathrm{~K}$ : ta tuleb (.) kella kaheksaks tavaliselt,

he come:3sg clock:GEN eight:TrA usually

'He usually arrives at eight.'

Öelge projects a continuation of the turn, which is witnessed by the interlocutor's silence during the pause in line (4). If palun öelge 'please tell (me)' had been a full turn construction unit on its own, the speaker $\mathrm{K}$ could have responded in this space. The projection achieved by öelge is partly actional, as it projects a specific further action, and partly grammatical, as it projects an object. The two types of projection are, of course, interdependent (Auer 2005), as interaction is the primordial locus of the emergence and implementation of grammar. As a strong projector of a same-turn continuation, öelge is a device of turn-design. 
In terms of the semantic/pragmatic meaning, the imperative of 'say' explicitly orders the recipient to say something. It thereby makes relevant a response, which is indeed provided in line (6). Epistemically, öelge as a straightforward imperative marks certainty that the recipient will have the answer to the upcoming question. The content of what the interlocutor is expected to 'say' is yet to come, as öelge does not convey anything about the semantics of what is coming up. Instead, it projects the action type that will be carried out in the ongoing turn, asking a question. The action itself is yet to be provided.

Crucially, Estonian clauses do not regularly reveal their dependency status via word order or auxiliaries. It is only marginally possible to construct inversion yes/ no questions that will be discussed below. The clause in Example (5) thus has two alternative translations, shown as (a) and (b).

\section{(lines 4-5, Example 5)}

mis kell omme Siivelt Alo tööle tuleb(? clause)

what time tomorrow NAME NAME work:ALL come:3sG

a. 'when Siivelt Alo will arrive at work tomorrow' (dependent clause)

b. 'When will Siivelt Alo arrive at work tomorrow?' (independent clause)

Below, variant $b$ will be used in all the translations, but the reader is requested to always keep variant $a$ in mind, as for the speakers of Estonian both variants are equally possible.

Characteristically, öelge in Example (5) initiates the topic of reason-for-call and in institutional calls regularly collocates with the polite palun 'please'. In fact, the plural form öelge hardly ever occurs without palun ${ }^{1}$. Palun öelge, and especially öelge palun seems to be a recurrent way of initiating a question and the first topic in an institutional call. All the telemarketers in the LK corpus use the formulaic öelge palun or palun öelge to initiate the first and only topic of marketing calls, which is why the overall frequency of öelge is very high (50 cases in all). The TA corpus also includes numerous cases of öelge (59 in all). A large share of the instances there come from call centers (33), which may reflect the high epistemic expectation that the recipient will have the answer. A typical example follows.
(6) $1 \mathrm{~V}$ : infotelefon
Ker[sti tere,]
information.line NAME hi
'Information line, Kersti, hi!'

1. Interestingly, palun itself has grammaticalized into a pragmatic particle from a verb form 'I beg' and it also occurs as a question preface, as in palun kuhu te elistate 'please/excuse me, where are you calling?' (Keevallik 2003: 140-153). 
$2 \mathrm{H}$ :

[tere palun] öelg(e)

hi please tell:IMP;2PL

'Hi, please öelge'

3 kuskohas Pärnus on ilusalong Dione. where:INS NAME:INS is beauty.parlor NAME where is the beauty parlor Dione in Pärnu?

$4 \mathrm{~V}$ : ̈̈ks hetk,

one moment

'One moment'

Thus, öelge + palun + question is a format that is used in institutional single-task calls to initiate the first and often the only topic of the call. This kind of so-called question frames have been claimed to be characteristic of institutional discourse, at least what concerns their Swedish counterparts (Lindholm \& Lindström 2003: 52-57). However, ütle/öelge is not restricted to institutional calls. Example (7) demonstrates identical usage in a non-institutional call between members of the same housing unit. As these speakers address each other in singular, the verb occurs in singular.

(7) $1 \mathrm{H}$ : =tere Alo. kuule Veiko Tohter on siin.

hi NAME KUULE NAME NAME is here

'Hi Alo, listen, Veiko Tohter here'.

2 I: noh,

'Yeah'

$3 \mathrm{H}$ : .hh kule ütle palun kudas hh edeneb

KULE tell;IMP;2sG please how progress:3sG

'Listen ütle please how is it going'

4 meil seehh erastamine meil sealwe:ADs this privatization we:ADs there

'with the privatization there?'

$5 \mathrm{I}:$ ei edene, ei edene.=

NEG progress NEG progress

'It's not.'

In non-institutional conversations, ütle frequently follows the informal turn-initial kule, originally kuule 'listen:IMP:2SG', which is regularly used to present the reason for the call in Estonian and several adjacent cultures (Hakulinen et al. 2003). While kule does not put constraints on the grammatical nature of the upcoming syntactic units (Keevallik 2003: 53-74), ütle projects an interrogative clause, a 
question for the interlocutor to be responded to. Both regularly initiate reason-forthe-call turns, thus displaying a certain amount of overlap in function.

However, the usage of ütle/öelge is not restricted to the beginning of a conversation. It may be used more widely to initiate and pursue alternative topics. In the middle of an ongoing conversation, öelge or ütle is used to project a question that initiates a new (sub)topic. In Example (8), the speaker E is describing some logistical matters of a Christmas performance, when A starts competing for the turn with an information request concerning the length of the performance. This competing topic is initiated with an ütle-question.

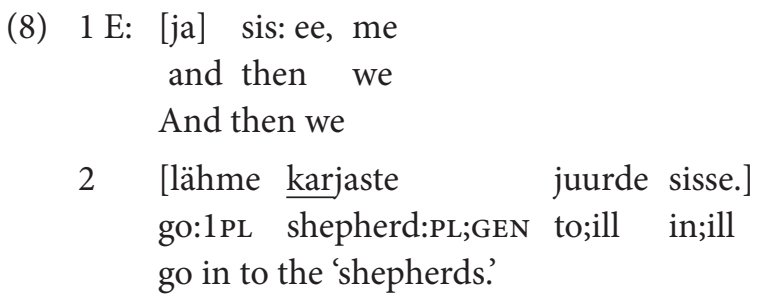
3 A: [ütle mitu minutit Ene ] say;IMP;2sG many minute:PRT name 'Ütle Ene how many minutes'
4 see kokku tuli präägu.
this together come:IMF;3sG now 'the whole thing is now?'

$\begin{array}{rlll}5 \mathrm{E}: \text { h ee, eks ta tuleb } & \text { umbes pool tundi. } \\ \text { EKs it come:3sG } & \text { about half hour;PRT }\end{array}$ 'Well it should be about half an hour'.

A's question in lines (3-4) is an initiation of a longer sequence concerning the problem that too few people would be able to see the show, as the space for the audience is limited. On the other hand, the show is planned to run several times, which is why its length is of importance. The ütle-initiated turn thus initiates a whole new topical and action sequence. It breaks the ongoing logistical explanation by $\mathrm{E}$ and makes an answer by her a next relevant action. Ütle initiates a new local trajectory for the conversation.

The speaker A initiates the turn and the topic in overlap, without reacting to the prior turn. Being an item that only defines the nature of the upcoming turn without giving away any of its semantic content, ütle is a suitable turn-claiming device to be produced in overlap. It need not be properly heard. Ütle is a device for the next speaker to escape the sequential context and contingencies of the prior turn. Every turn is inescapably produced in the given context and $\ddot{u} t l e$ addresses this problem as a displacement marker that locally accomplishes a shift from the 
relevant next action to an initiation of something new. It has been argued that imperatives generally claim noteworthiness and can therefore develop into this kind of turn-claiming items (Waltereit 2002). It seems, though, that any item that is regularly turn-initial, may also function as a turn-claiming item, including some imperatives.

In all of the examples with the imperative of 'say' + interrogative clause, the recipient of the turn responds by answering the question. This proves that the interrogative clause is profiled in conversation. It constitutes the main focus for the participants that attend to the interrogative. Subsequent action by the recipient is the criterion used by Sandra Thompson (2002: 131-134) to demonstrate that the "complement clause" is profiled in interaction. She argues that claims on which clause is profiled in a grammatical structure need to refer to the course of actions that the participants are engaged in. Thompson demonstrates that in conversational data the profiles of this type of "complement clause" regularly override those of the "main clause", because the recipients of these turns typically orient to the "complement clause" in their subsequent actions. Accordingly, when the Estonian speakers regularly orient to the interrogative clause as making relevant an answer, it is interactionally profiled and overrides the "main clause".

In the case of ütle/öelge, however, the main clause also gets a response, as in it the interlocutor is literally urged to say something and she indeed does. At the same time, the imperative is quite redundant - a question alone would have accomplished exactly the same task of pursuing an answer to the question. This is one reason for looking closer into when and why these questions are designed with the preface. The general pattern that emerges for ütle/öelge-question is that they are not evenly distributed across all the data. As has become clear in the examples above, they are specifically used to initiate a new topic and sequence, including the initiation of the first topic of telephone calls. Their function is to create structure in the conversation. The imperative CTP preface marks a distinct action boundary in interaction, making salient certain transitions between larger chunks of talk.

Besides the distributional pattern, there are also grammatical and turn-constructional reasons for considering ütle/öelge a question preface rather than a main clause. For example, while projecting the action type of the upcoming turn, it does not have to be adjacent to the question. The interrogative clause can be produced further down the turn after an intervening segment, which should be impossible in case ütle/öelge was truly a main clause, as CTPs precede their complements in Estonian. Excerpt (9) illustrates this point. In this telemarketing call, the segment that immediately follows öelge palun 'tell me please' is not a question but a statement. After öelge palun the telemarketer introduces some background information to the question he is about to pose. At the same time, öelge palun still projects a question. There is no final prosody at the end of the statement about the 
complementary subscription, and the turn is not pragmatically complete either. Accordingly, the interlocutor refrains from taking the turn until the question has been produced.

(9) $1 \mathrm{M}:[. \mathrm{h}]$ öelge palun te tegite

tell:IMP;2PL please you:PL do:IMF:2PL

'Öelge please, you made an introductory'

2 tutvumistellimuse Liivi introductory.subscription:GEN NAME 'subscription for Liivi Linnaleht,'

3 Linnalehele, kas leht käib NAME:ALL QUES paper go:3sG 'do you receive the paper'

4 teil präegu.

you:PL:ADS now

'at the moment?'

$5 \mathrm{~K}$ : jaa tänan, $\underline{\text { käib, }}=$

yeah thank.you go:3sG

'Yeah I do, thank you'

Interlocutors treat ütle/öelge as projecting a request for information. Other units may come in between but the speakers do not treat their completion as a transition relevance place, i.e. a place where the other speaker could start speaking. The turninitial imperative of 'say' can thus be used to initiate longer multi-unit turns ending in an information request. This interactional structure, where a segment projects an action which is then delayed by another unit, has been described by Schegloff (1980). Although the projective segments discussed by him are clausal, such as let me ask you this or can I ask you a question, the Estonian single word ütle/öelge functions in a similar way with the exception that the segment itself never elicits a recipient response (a go-ahead). Furthermore, the upcoming side-unit is rarely responded to by the recipient. The whole format is thus much more concise in the case of Estonian ütle/öelge which seems to be a device for turn-design rather than an entire action sequence. However, just as described by Schegloff (1980: 114) for English, and Lindholm and Lindström (2003: 50) for Swedish, the side-units following the projective segments introduce the referent. In the above example, the referent is the subscription to the newspaper that the upcoming question concerns. The side-unit after the initial projection of a question is produced and heard as being in the service of the projected action. Its beginning latches prosodically smoothly to the preface and the falling pitch at its end is not interpreted as a place where the next speaker can take the turn. 


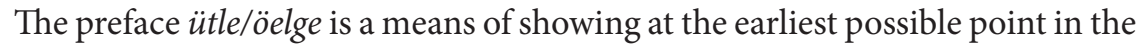
turn that an information request is coming up. It projects a question which does not have to occur adjacent to it and cannot therefore be considered its complement. Additional evidence of the autonomy of the CTP and the interrogative clause can be found in cases where ütle/öelge occurs within a particle chain. In these cases the CTP is not adjacent to the interrogative clause either. In Example (10), ütle is used turn-initially among other pragmatic particles. The question it projects is produced after the particle chain including kuule, approx. 'listen', ütle, aga 'but', and näiteks 'for example'.

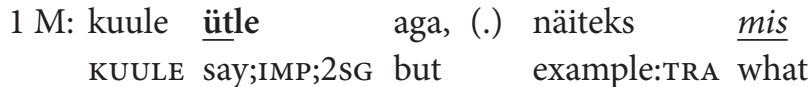

$$
\begin{aligned}
& \text { 'Listen ütle but, (.) for example what' } \\
& 2 \text { emotsioonid sind valdaksid, kui sa } \\
& \text { emotion:PL you:PRT fill:COND:3PL if you } \\
& \text { 'emotions would you have if you were' } \\
& 3 \text { oleksid juba vanaema. } \\
& \text { be:COND:2sG already grandmother } \\
& \text { 'a grandmother already?' }
\end{aligned}
$$

Finally, there is word order evidence that $\ddot{u} t l e / \ddot{e}$ lge is a question preface rather than a main clause. There is one optional syntactic difference between independent and dependent interrogative clauses in Estonian and that is inversion in yes/ no questions. Inversion cannot be used in dependent interrogative clauses, while it is occasionally used in main clauses. And it occurs after ütle/öelge, as in Example (11). This is the grammatical evidence that the interrogative clause used after $\ddot{u} t l e$ should be analyzed as an independent clause and not as a complement.

(11) $1 \mathrm{E}$ : halloo. Ene kuuleb.

hello NAME listen:3sg

'Hello, Ene listening.'

$2 \mathrm{H}$ : tere:. Klaarika siinpool.

hi NAME here

'Hi! Klaarika here'.

$3 \mathrm{E}: \mathrm{mhmh}$ ?

'Uhuh'

$4 \mathrm{H}$ : .h ütle on sul Kristeli: telefon. say;IMP;2SG is you:ADS NAME:GEN phone 'Ütle do you have Kristel's phone number?'

$5 \quad(0.7)$ 


\section{$6 \mathrm{H}$ : on tal üldse telefoni. \\ is she:ADS ÜLDSE phone:PRT \\ 'Does she have a phone?'}

There are thus two types of syntactic evidence that the interrogative clauses projected by ütle/öelge are not subordinate or dependent. First, they may be non-adjacent to the CTP and second, inversion may be used. The reasons for the preface implementation are rather interactional, concerning turn-design and sequencing of actions in a conversation.

In addition to the syntactic evidence, prosodic features suggest that $\ddot{u} t l e / \ddot{o} e l g e$ is not profiled for the participants. It is often incorporated into the following intonation unit as an enclitic element. Occasionally, it carries some amount of stress or a high onset as is characteristic of reason-for-the-call turns (Couper-Kuhlen 2001) but it does not stand out as the most heavily stressed item in the turn or utterance. Instead, it is often produced quicker than the upcoming question and could therefore be heard as subsidiary to $\mathrm{it}^{2}$. The pitch peak is regularly on another item, as shown in Figure 1.

In summary, there is hardly any reason to analyze the interrogative clauses following ütle/öelge as subordinate complements. Ütle/öelge indeed projects a question but since it is not necessarily adjacent to the interrogative clause, it cannot be considered a CTP. Rather, it structures the conversation by making explicit the initiations of new topics, functioning like a particle. In fact, it is not uncommon for an

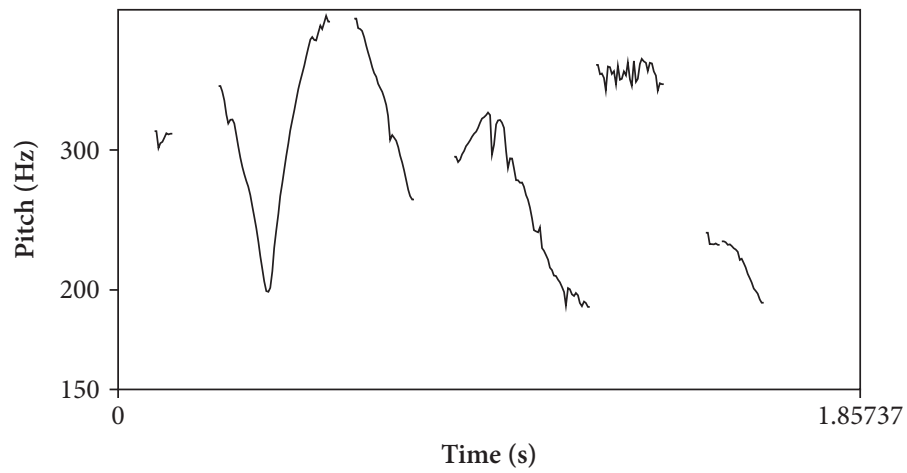

Ütle onsul Kristeli telefon

Figure 1. The pitch contour of Example (11), line (4)

2. In a similar way, the corresponding Swedish question-projecting phrase jag undrar 'I wonder' has been shown to have subordinate prosody with no stress and higher tempo than the surrounding units (Lindström 2002: 65).

(C) 2011. John Benjamins Publishing Company

All rights reserved 
imperative matrix clause to diachronically develop into a particle (Brinton 2001). Ütle/öelge provides a metapragmatic frame anticipating the following segment, as has been shown for e.g. N-be-that-constructions, pseudo-clefts and extrapolations in German (Günthner 2008, this volume; Hopper \& Thompson 2008).

At the same time, the CTP ütle/öelge may be part of an entire clause, when projecting the turn type and structuring conversation in the above ways. Formats such as ütle mulle seda 'tell me this' and ütle mulle niisugust asja 'tell me such a thing' occur, where the cataphoric pronoun seda 'this' and proadjective niisugust 'such' further highlight the projecting nature of the clause. This means that the verb-only format is but one device among a number of functionally identical semantically relatively empty formats for question projection, some of which are more prominent by virtue of their length.

However, there is one positional feature that is idiosyncratic to the verb-only format. It is marginally possible to use at least the singular ütle at the end of the turn, after the interrogative clause (a single case in the corpora).

$$
\begin{aligned}
& 1 \mathrm{R}: \\
& \text { kule, mis pääval teil vaheaeg } \\
& \text { KULE which day:ADS you:PL:ADs vacation } \\
& \text { 'Listen, when will your school vacation' } \\
& 2 \text { akkab koolis ütle. } \\
& \text { start:3sG school:INs say;IMP;2SG } \\
& \text { 'start ütle?' }
\end{aligned}
$$

$3 \mathrm{E}: \mathrm{mm},(0.2) \mathrm{ma}$ arvan et üheksateiskümnendast.

I think:1sG that nineteenth:ELT

'Um, (0.2) on the nineteenth, I think.'

Importantly, this is a topic initiation similar to all the other cases of ütle/öelge usage presented earlier. The topical break is also marked by the turn-initial kule, approx. 'listen'. Like in the cases described above, ütle is here prosodically part of the same unit as the interrogative clause. The intonation does not fall before the turn-final ütle. Also, the interrogative receives an answer. Sequentially and compositionally, this format is identical to the ones described above. However, the turnfinal $\ddot{u} t l e$ is heard as an insisting item, reinforcing the question. Rather than projecting the question, it is here retroactively pushing for a response. It is a more pronounced epistemic device than its turn-initial relative, because of this insisting force. The mobility of ütle in a turn underscores its nature of a particle, since an imperative CTP can never occur after the complement clause in Estonian. Ütle/ öelge is not a main clause but an interactional and interpersonal element of question design, a particle that cannot take complements. It is indeed important for the participants, but at a different organizational level as compared to the interrogative clause that sets the action trajectory for the next turn.

(C) 2011. John Benjamins Publishing Company

All rights reserved 


\section{Projecting actions 2: The imperative of 'tell, talk'}

The second person imperative form of räägi 'tell, talk' is used very similarly to the imperative of 'say' in conversation. It is somewhat less frequent, and in contrast to 'say', the plural form räägite is not used with interrogative clauses in the available corpora. This is not a coincidence, as the format of imperative of 'tell, talk' + interrogative clause is characteristic of informal style and the verb can thus be expected to occur in singular only. In everyday interaction, the choice between the two verbs is to some extent idiomatic.

Similarly to ütle/öelge, the turn-initial rä̈gi initiates a new or the very first topic in conversation. Produced immediately after a self-introduction or a greeting, it cannot constitute a turn on its own, because it does not provide a complete action. It is therefore understood as projecting a continuation by the same speaker, specifically showing that an information request is coming up. Example (13) is a case in point, where after the call-taker's response to the summons in line (1) the caller initiates an information request with räägi immediately after the greeting.

(13) 1 P: jaa,

'Yeah'

$2 \mathrm{~V}$ : no tere. räägi kuidas sul

No hi tell;IMP;2sG how you:ADs

'Hi räägi how did (it)'

3 läks täna.

go;IMF;3sG today

'go today?'

$4 \quad(2.0)$

It turns out, however, that $\mathrm{P}$ is not the person that the caller hoped would pick up the phone. Therefore there is a long pause after the elicitation and no response to the question. In its literal meaning, 'telling, talking' implies a longer account from the interlocutor than 'saying. This may be reflected in the above example with an open question. However, räägi is also used to initiate polar questions with potentially simple short answers identically to ütle/öelge, as happens in Example (14).

$$
\begin{aligned}
1 \mathrm{H}: \text { /-/ kesse kuuleb seal. } \\
\text { who listen:3sG there } \\
\text { 'Who is listening?' }
\end{aligned}
$$

$2 \mathrm{~V}$ : Üllar?

NAME

'Üllar.' 
$3 \mathrm{H}$ : Üllar oled jah? (.) kule räägi

NAME be:2SG yeah KULE tell;IMP;2SG

'You're Üllar. Listen, räägi'

4 kas sul vanaema ka kodus

QUES you:ADS granny too home:INS

'is your granny at home'

5 [on $v \ddot{a}$.

is QUES

'too?'

$6 \mathrm{~V}$ : [jaa,] ma kutsun kohe.

yeah I call:1sg at.once

'Yeah, I'll call her right away'.

A yes/no interrogative basically makes relevant a one-word answer, as far as the grammar is concerned. The action it implements, however, may be varied. In the above case, the question is a request for another speaker, which is complied with in line (6). Nevertheless, the 'telling' elicited by the räägi-initiated question is very short, which demonstrates the semantic bleaching of räägi. This is characteristic of the grammaticalization process of particles.

Similarly to the ütle/öelge pattern, there are both syntactic and prosodic indications to suggest that räägi + interrogative clause cannot be analyzed as main clause + complement. Syntactically, räägi may be implemented before interrogative clauses with inversion, whose analysis as complements is impossible.

(15) $1 \mathrm{M}$ : -lo

$2 \mathrm{~K}$ : tere.

'Hi!'

$3 \mathrm{M}$ : tere,

'Hi!'

$4 \mathrm{~K}$ : kule räägi on sul see: $m,(.) \mathrm{mm}$

KULE tell;IMP;2SG is you:ADS this

'Listen räägi, do you have the'

5 selle ambaarsti see, kaart seal

this;GEN dentist:GeN this card there

'dentist card somewhere'

6 kuskil käepärast. ks sa ütleks mulle somewhere at.hand QUES you say:COND I:ALL

'there at hand. Would you tell me' 
7 selle telefoninumbri mis seal peal on. this;GEN phone.number:GEN that there on is 'the phone number that's on it.'

9 M: vot ei ole.

VOT NEG be

'I don't'

Prosodically, the item is latched to the upcoming prosodic unit, similarly to ütle/ öelge. Even when there is some amount of stress on räägi, it never constitutes a prosodic unit on its own and always projects a continuation. There is no stress on räägi in the above Example (15) and the highest pitch is on the first word of the interrogative clause, as shown in Figure 2. The prosodic features of räägi suggest that the speakers do not necessarily treat it as the profiled main clause but as something subsidiary to the interrogative clause.

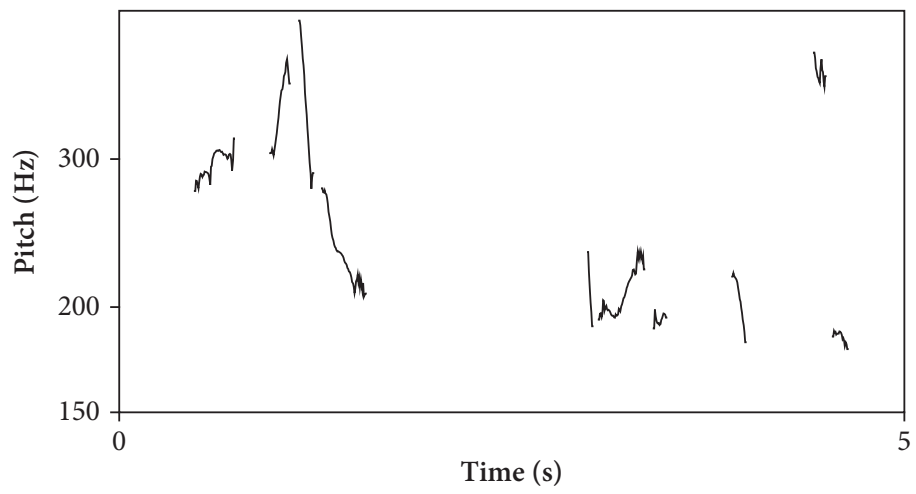

Räägi on sulsee ambaars tikaart sealkuskil käepärast

Figure 2. The pitch contour of Example (15), lines (4-6)

Similarly to ütle/öelge, räägi can be applied to project a question further down the turn. The question does not have to be adjacent to the projective item itself. Also, it can be part of a longer clausal format, such as räägi seda 'tell (me) this', which is functionally identical with the short format. However, only the latter can appear turn-finally, as shown in Example (16).

(16) $1 \mathrm{P}$ : jaa ma kuulen, yeah I listen:1sG

'Yeah, listening'

$2 \mathrm{E}$ : tere Pille, Ene siin.

hi NAME NAME here

'Hi Pille, Ene's here'. 
3 P: tere Ene.

'Hi Ene'

4 E: no kuidas läks.

No how go:IMF;3sG

'How did (it) go?'

$5 \quad(0.7)$

6 P: ma just jõudsime.

I just arrive:IMF:1PL

'I/we just came in.'

$7 \mathrm{E}: \mathrm{mhmh},<=$ no kuidas läks $\underline{\text { räägi. }}$

uhuh No how go:IMF;3sg tell;IMP;2sG

'Uhuh, how did (it) go räägi!'

8 P: täitsa normaalselt läks. /—/

quite normally go:IMF;3sG

'Quite okay'.

In this call, räägi is used while trying to initiate the first topic of the call, as was shown above with the turn-initial usage (Example (15)), albeit in this case it is the second attempt. While the imperative to talk always implies that the recipient of the turn is able to provide the necessary information, the epistemic connotation seems to be even stronger in turn-final usage. It restates that an answer is strongly expected after the question has already been produced. The insisting character of the format is in this particular case (the only one of its kind in the corpora) used to re-launch the question that was already posed in line (4) but did not receive an answer. The mobility of rä̈gi within the turn and in relation to the interrogative clause suggests that they are independent units and that there is no subordinating relationship between the two. As a particle, räägi does not have the ability to take object complements and it does not define any grammatical feature in the interrogative clause. Consequently, the interrogative clauses following and projected by räägi are to be considered independent.

The format rä̈gi + interrogative clause usually elicits a telling from the interlocutor. It is regularly used in topic-initiations, as a means of overtly marking the topical structure of the conversation. It sometimes implies longer accounts than ütle/öelge and is more characteristic of informal talk. Turn-initially, both of these items project the type of action that the turn will be doing, namely asking a question. Neither of them carries any semantic information about the content of the upcoming unit, apart from conveying the assumption that the recipient will be able to answer the question. They project the action of information request in the current turn, while not yet doing the action itself. This is characteristic of question 
frames cross-linguistically. For example, Swedish question frames, such as far jag fråga 'can I ask', jag tänkte fråga 'I thought I'd ask' and jag undrar 'I wonder' function in the same way (Lindholm \& Lindström 2003: 41) 3 $^{3}$ At the same time, all of these formats also project what the next speaker is expected to do after the current turn has been terminated, namely, to answer the question. They thus help the speakers to coordinate their actions in time, which is a basic challenge for participants in interaction.

\section{Marking intersubjective uncertainty: The negation of 'know'}

The third very common CTP that is regularly used before interrogative clauses in conversational Estonian is (ei) tea 'don't know'. Similarly to the above particles, (ei) tea projects more talk by the current speaker. Consider the following Example (17) from a call to the reception of a medical center.

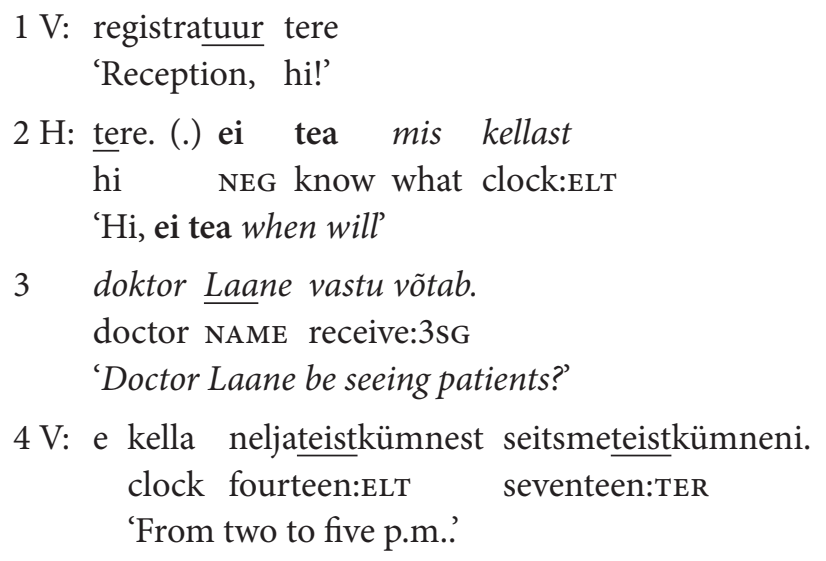

$4 \mathrm{~V}$ : e kella neljateistkümnest seitsmeteistkümneni. clock fourteen:ELT seventeen:TER 'From two to five p.m..'

The turn in lines (2-3) involves a projective ei tea and an interrogative clause. It is treated as a question by its recipient, as is evidenced by his answer in line (4). Formally, however, ei tea 'don't know' + interrogative clause constitute a statement about speaker knowledge. In translation, that would mean '(I/you) don't know when doctor Laane will be seeing patients'. Indeed, the longer patterns with pronouns, te ei tea 'you:PL don't know' and sa ei tea 'you:SG don't know' also occur in identical function, and the shorter version (ei) tea is likely to have developed from these in the process of grammaticalization (Keevallik 2006). In its shortest form,

3. Estonians generally tolerate more imperatives than Swedes, who use more interrogatives and modals to formulate e.g. directives (Tulviste et al. 2002). The two imperative patterns in this study may in fact reflect the Estonian direct speaking style. 
only tea 'know' is used. In Example (18) tea + interrogative clause is interpreted as a question by $M$, who answers it in lines (7-9) after an insertion sequence.

(18) 1 R: tea kas sul vanaema juba know QUES you:ADS grandmother already 'Tea did your grandmother receive'

2 sai sünnipäevakaardi kätte.

get:IMF;3sG birthday.card:GEN hand;ILL the birthday card already?

$3 \mathrm{M}$ : millal sa posti panid.

when you post;ILL put:IMF:2sG

'When did you post it?'

$4 \mathrm{R}$ : laupäeva ommikul siis kui Saturday;GEN morning:ADS then when 'On Saturday morning when we went'

5 sides käisime. post.office:INS go:IMF:1PL to the post office.

$7 \mathrm{M}$ : <kui laupäeva omikul posti pani:

if Saturday:GEN morning:ADS post;ILL put:IMF 'If (you) posted it on Saturday morning'

8 sis ta peaks> täna kätte then she must:Cond today hand;ILL 'then she should have received'

9 saand olema:. get:PPT be:sup 'it today'.

In the above Examples (17-18), the interrogative clause is treated as implementing the main action in the turn. The recipients respond to the interrogative clause and not to the CTP clause that makes a statement about knowledge. In other words, the participants analyzed the "complement" to be profiled. This is an argument for not considering ei tea the main clause in the above examples. Instead, (ei) tea functions as an epistemic expressing the speaker's stance. This stance stems from its original meaning of 'not knowing' something. (Ei) tea-questions are in fact regularly implemented in cases when the recipient of the question is quite likely to lack the knowledge to respond to the question. There is thus an interesting conflict between the assumption that the recipient is not likely know and asking anyway, in 
case she does. Example (19) comes from a conversation between two sisters who discuss whether a third sister would like to join them at their father's birthday. The recipient of the question does not necessarily have this knowledge, just like the recipient in Example (18) above is quite likely not to have information about whether his grandmother has already got her birthday card. This assumed uncertainty by the recipient is expressed in the (ei) tea-preface to the question.

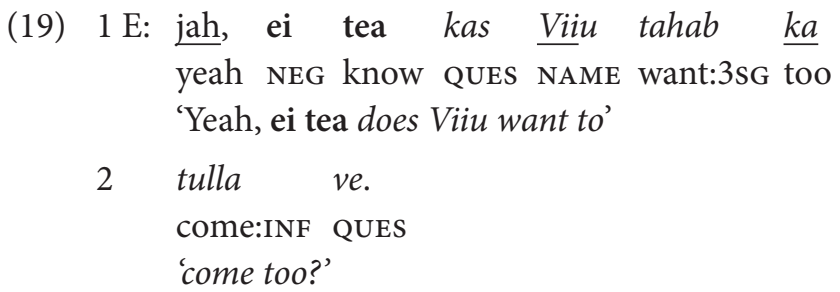

As it turns out, responses to questions in Examples (18) and (19) are accordingly epistemically marked. The 'should' in Example (18) and 'probably' in Example (19) mark epistemic uncertainty. Their producers thus confirm the prior speaker's assumption that they do not have definite knowledge of the matter asked about. The question preface (ei) tea marks uncertainty, especially the assumed lack of knowledge by the recipient of the projected question. In Example (17), however, the strategy is employed for politeness reasons. It is less imposing to request information while at least formally leaving open the possibility that the recipient may not have the knowledge. In this way, the (ei) tea-format also deals with the appropriateness of the question posed to the current recipient. Questions are by definition addressed to knowing recipients and (ei) tea marks that this condition may not be fulfilled. Implying that the question may not be properly addressed eases the burden of answering for the recipient and diminishes the imposition on her autonomy.

Besides, avoiding person reference with items such as (ei) tea helps to conceal who the implied non-knowing subject is and thereby minimizes the threat to the recipient's social face. The negation ei tea in Estonian can be applied to all persons and numbers, since verbs are not conjugated in the negative form. In the above examples, it can be anybody who lacks the knowledge, not necessarily the speaker or the hearer. Although the pattern has most probably developed from sa ei tea 'you don't know', the insinuation of recipient's lack of knowledge (Keevallik 2006: 179-181), the question preface (ei) tea does not make this explicit. This distinguishes the Estonian (ei) tea from pragmatically similar question prefaces in other languages, such as the Swedish jag undrar 'I wonder', which underlines speaker's 
lack of knowledge (Lindström 2002: 64-65), and the English I wonder ${ }^{4}$. All of the items claim lack of knowledge but the Swedish and English ones mention an agent. It is clear who the non-knowing subject is. In contrast, personal reference is avoided in the Estonian format, as it is on a wide scale in the Estonian speech community (Erelt 1990, Keevallik 1999: 130-131, Keevallik 2006: 189-191). The (ei) teaformat enables the speaker to pose the question in a generic impersonal manner and eases the contextual constraints on answering it in the next turn. Interactionally, this contrasts with the imperative-prefaced questions that assumed recipient knowledge and obliged them to answer. Indeed, the questions are sometimes treated as rhetorical (Keevallik 2006: 186-189). To summarize, there is interactional evidence in participant behavior that the interrogative clause is the profiled clause, independent and attended to by the next speaker. At the same time, (ei) tea is an epistemically downgrading preface that achieves certain interactional ends.

The independence of the interrogative clause is further supported by grammatical evidence. First, a dependent interrogative clause cannot be terminated with the turn-final question particle $v e / v a ̈$ 'or', as the ei tea-prefaced interrogative clause does in Example (19). Second, inversion cannot be used in dependent clauses, but occurs in (ei) tea-prefaced questions, as shown in Example (20).

(20) Ei tea on mul õigus või mitte

NEG know is I:ADs right or not

'Ei tea am I right or not?'

(NET)

These cases demonstrate that the interrogative clauses following (ei) tea are not syntactically dependent. Additional evidence can be provided by showing that $e i$ tea (i.e. with the negation word) is mobile in the turn, thus behaving like an epistemic phrase. It does not have to occur utterance-initially, as epistemic stance may be added after the modified unit has been terminated. This kind of mobility has, for example, been shown for the English epistemic phrase I guess (Thompson \& Mulac 1991). The turn-final usage of the epistemic ei tea is demonstrated in Example (21), where the telemarketer terminates his question with it, adding the epistemic stance after the question has been terminated.

$$
\begin{aligned}
& \text { 1 M: a millal ta tuleb ei tea. } \\
& \text { but when she come:3sG NEG know } \\
& \text { 'But when (will) she come back ei tea?' } \\
& 2 \text { P: .h vot mai tea./-/ } \\
& \text { vot I:NEG know }
\end{aligned}
$$

4. In requests, the English I wonder addresses the entitlement of the speaker to have the request granted (Curl \& Drew 2008). This does not seem to be an issue with the preface (ei) tea. 
'I really don't know'

The epistemic ei tea can furthermore occur in the middle of the interrogative clause.

1 Millest see ei tea tuleb et mõnel
what:ELT this NEG know come:3sG that some:ADS
'What it ei tea depends on that some get (it)'
2 läheb tööle ja mõnel mitte
go:3sG work:ALL and some:ADs NEG
'to work and some not?'

In these cases, it is impossible to argue that the interrogative clause is in any way subordinated to ei tea. Rather, ei tea is embedded in or added to the interrogative clause for the purposes of expressing an epistemic stance.

Even prosodically, (ei) tea is usually non-prominent with regard to the interrogative clause and incorporated into the preceding, following, or ongoing intonation unit. Occasionally it displays a certain amount of stress, as in Example (17) but it still forms a single coherent prosodic contour together with the interrogative clause. Unfortunately the quality of these examples does not allow drawing pitch curves.

In contemporary informal Estonian, the original negative verb form (ei) tea has become a mobile epistemic device for question design, the aim of which is to mark the posed question as potentially unanswerable by the current recipient. As such, it can also be implemented for politeness purposes. The speakers treat the format (ei) tea + interrogative clause as a modified question that makes relevant an answer, albeit contingent upon availability of knowledge. While the interrogative clause is thereby analyzed as profiled and autonomous, (ei) tea attends to the interpersonal dimensions of its production in the current situation for the present participants.

\section{Marking topical continuity across sequences: The adjective 'interesting'}

The last format under discussion, the assessment word $u v i t a v^{5}+$ interrogative clause, is different from the previous ones because it does not contain a verb as one of the two components. Its first part can be seen as an elliptical predicate adjective clause 'it is interesting', while the second half constitutes the subject clause, containing the information about what the interesting thing is. In the following example, 'interesting' precedes an interrogative clause inquiring about an aspect of what has just been reported by another participant. In lines (1-2), M quotes his grandmother.

5. In standard language, the word is huvitav but in colloquial usage, word-initial $h$ is customarily dropped in Estonian.

(C) 2011. John Benjamins Publishing Company

All rights reserved 
(23) $1 \mathrm{M}:<\mathrm{Q}$ küll on ikka tubli: naine sel KÜLL is IKKA able wife this:ADs "What an able wife Meelis has,"

2 Meelisel, Q> nimodi ta koguaeg ju mõtleb NAME:ADS like.this she always JU think:3sG 'she thinks like this all the time and sighs'

3 ja ohkab ja räägib teistele ka. and sigh:3sg and tell:3sg others:ALL too 'and tells everybody else too.'

4R:@

$5 \mathrm{M}$ : päriselt. (.) ma juba tian oma vanaema. really I JUBA know:1sG own granny 'Really. (.) I know my granny'.

6 R: jah, 'Yeah?'

$7 \mathrm{M}$ : jaa, 'Yeah.'

9 R: uvitav miks ma talle meeldin. interesting why I she:ALL please:1sG 'Uvitav why does she like me.'

$$
\begin{array}{llll}
10 \mathrm{M} & \text { noh, (0.8) sa oled ju: (0.5) nii tore. } \\
\text { NOH } & \text { you be:2sG Ju } & \text { so friendly } \\
\text { 'Well, (.) you are (0.5) so friendly'. } &
\end{array}
$$

The assessment uvitav in line (9) could be retrospective, commenting on what $\mathrm{M}$ just reported and thus a pragmatically complete turn. However, it is produced as part of the upcoming turn, projecting an expansion on what exactly is 'interesting' (see Couper-Kuhlen and Thompson (2008) on retrospective and prospective assessments and "extraposition" in English). It could be followed by a declarative as well as an interrogative clause, so it is not unambiguously projecting a question, like the above verbs did.

Before looking closer at the format uvitav + interrogative clause, let us look at a more general syntactic pattern that it represents. The pattern concerns a number of other assessment words, such as hea 'good', kahju 'pity', and tore 'great'. These words regularly occur without the copula and any correlate word before clauses that explicate what is assessed by them. There is a distinct pattern in Estonian, in which assessment words are used with what are formally complement clauses, 
e.g. initiated by the complementizer et. The words are more adequately analyzed as stance-taking devices in regard to the upcoming clause (Keevallik 2010). It has been argued that a similar pattern in German is a result of a grammaticalization of the respective full matrix clauses involving the copula (Auer 1996: 315-320). In the process, original reactive adverbials and one adjective gut 'good' have become projective utterance-initial items in conversation. According to this account, the pattern is to be considered elliptical, at least historically. In contrast with the pattern described by Auer, Estonian pattern involves a considerable number of different adjectives (Keevallik 2010). Examples (24-26) display cases of declarative subject clauses used in combination with assessment words, an adjective (24) and an adverbial (25) that very frequently occur in this syntactic pattern.

(24) $\mathrm{H}$ : selge no igal juhul hea et sa oled veel clear No anyway good that you be:2sG still 'Okay. Anyway, (it is) good that you are still' reedel Tartus.

Friday:ADS NAME:INS 'in Tartu on Friday.'

(25) P: kahju et sa ei saa tulla. pity that you NEG can come:INF '(What a) pity that you cannot come.'

1 M: hh \% e $\begin{aligned} & \text { uvitav et ma:: \% enne } \\ & \text { interesting that I earlier } \\ & \text { '(It's) interesting that I checked' }\end{aligned}$
2 neid pileteid
these:PRT Sweden;GEN ticket:PL:PRT
'these tickets to Sweden earlier'
kontrollisin. siis öeldi et kõik
check:IMF:1sG then say:IMs:IMF that everything
'(and I) was told that everything'
on nagu korras. =
is like in.order
'was alright.'

Utterances (24-25) constitute assessments on some reported state-of-affairs, where the upcoming complement clause contains the information on what the positive or negative assessment concerns. The word uvitav is different in this regard. Although it is inherently a positive evaluation, it regularly prefaces counter-arguments, and thus implies negativity. Example (26) is a response to a travel agent 
who claims not to have received money for some tickets. Instead of receiving the news about the unpaid ticket, the speaker puts forward a claim that she has been informed of the contrary and prefaces it with 'interesting'. In this way, turn-initial 'interesting' displays that some aspect of what has been said by the interlocutor is problematic and the aspect itself is explained in the following clause. In terms of the relative strength of the counter-argument, 'interesting' functions as a hedge. A claim that something is merely 'interesting' reduces the confrontational power of the upcoming utterance. In any case, none of the above assessment words besides uvitav can take an interrogative clause as a subject complement. There is thus a general pattern of combining assessment words with clauses in Estonian but only the ambivalent semantics of uvitav allows it to be combined with interrogative clauses, which will therefore be the focus of this subsection.

Similarly to the other patterns with interrogative clauses, the format with uvitav also does specific interactional work. The first example in (23), uvitav miks ma talle meeldin, approx. 'I wonder why she likes me', represents a typical case of its use. The utterance is produced in a position where the previous sequence has been terminated. Meelis (M) has reported that his granny likes his wife (R). R receives this information with a laughter syllable in line (4), which is apparently understood as expressing disbelief, because after it $\mathrm{M}$ reinforces his claim. After another round of incredulity by $\mathrm{R}$ and reinforcement by $\mathrm{M}$, the sequence is closed down. The uvitav-prefaced question after a long pause initiates a new sequence. At the same time, the question relates to the topic of the previous segment of talk, the claim that M's granny likes R. The two most distinct sequential features of uvitavprefaced questions is that they initiate new action sequences (like many questions do) and that they relate to an earlier topic, often the topic that was just discussed in the prior sequence.

Example (27) presents another case. The speakers have been gossiping about a guy Erki who has abandoned his family. In lines (1-2), V provides new information about Erkis background. This is received with a surprise token after which $\mathrm{V}$ provides the source of this information. In lines (7-8) $\mathrm{H}$ initiates a new sequence by asking an $u v i t a v$-prefaced question, suggesting a generalization on what $\mathrm{V}$ has just reported.

1 V: et Erki isa olevat ka Erki maha
ET NAME;GEN dad be:Quo too NAME;GEN behind
'Erki's dad had also left him behind'
2 omal ajal jätnud.
own:ADs time:ADs leave:PPT
'back in his days.'


$3(2.0)$

$4 \mathrm{H}$ : issand jumal.

'Good god!'

$5 \mathrm{~V}$ : sellest oli nüüd juttu. (0.8) Sille

that:ELT was now talk;PRT NAME

'(we) talked about that. (0.8) Sille'

6 nagu [mainis.]

like mention:IMF:3sG

'mentioned (it)'

$7 \mathrm{H}: \quad$ [uvitav] kas inimesed tõesti interesting QUES people really 'Uvitav do people really behave like this'

8 käituvad nimodi mallide järgi.

behave:3PL like.this pattern:PL;GEN according

'according to the patterns.'

$9 \mathrm{~V}$ : no vat ei tea jah,

NO VAT NEG know yeah

'Well, I don't know'

Grammatically, the utterance in lines (7-8) is formatted as a statement about something being interesting. It is not literally formatted as a question and therefore should not make relevant an answer. Nevertheless, the uvitav-prefaced interrogative clauses are regularly followed by answers to the interrogatives. This happens in both Examples (23) and (27) above. This demonstrates that the speakers indeed treat these utterances as asking a question. They never treat them as delivering an assessment (at least in the current corpora), which would make a second assessment or an agreement/disagreement the next relevant action. Thus, the interrogative clause interactionally overrides the importance of the turn-initial assessment.

At the same time, the grammatical fact that the $u v i t a v$-prefaced utterances are technically statements weakens the default assumption of a question that a recipient would have an answer to it. Uvitav therefore functions as an epistemic device, just like (ei) tea, to mark the speaker stance of uncertainty about whether the answer is available for the recipient(s). In addition, uvitav shows that the upcoming question is topically tied to prior talk, which is probably a reflection of its backward-looking evaluative role ${ }^{6}$. Uvitav-prefaced questions focus on a new aspect of

6. Even the rest of the assessment items presented in Examples (24-25) function similarly as topical bridges. All the words participating in the pattern can constitute retrospective assessments on their own (Keevallik 2010). 
what has already been talked about. Just like the above verbs/particles, uvitav organizes the sequential flow of conversation.

As an epistemic device, uvitav is not restricted to the utterance-initial position. There are altogether seven examples in the corpora in which it occurs turnfinally, which makes it the most frequent turn-final question frame studied here. Even in turn-final position, it displays no features of being a clause on its own. It is a pure epistemic, which can characteristically be added after the interrogative clause that it modifies. A case is shown in Example (28).

(28) A: mismoodi see värk kinni käib uvitav:?

how this thingy closed go:3sg interesting

'How to shut down this thingy uvitav?'

It is also possible to implement uvitav in the middle of the interrogative clause.
millal ta ministritööd huvitav teeb?
when he minister.job:PRT interesting do:3sG
'When does he uvitav do the minister's job?'

As in all the other patterns reported in this study, uvitav + interrogative clause cannot be analyzed in terms of the interrogative clause being subordinated to or dependent on the assessment term. Uvitav functions as an epistemic device that is mobile in terms of its placement with regard to the interrogative clause. Further grammatical evidence of the independence of the interrogative clause after interesting' is provided by the turn-final question particle $v \ddot{a} / v e$ 'or' that does not occur with dependent clauses, while it does occur at the end of interrogative clauses after uvitav.

$$
\begin{aligned}
& \text { (30) } 1 \mathrm{~K} \text { : uita } k s \text { see oli mingi väga vana } \\
& \text { interesting QUES this was some very old } \\
& \text { 'Uvitav was it a very old' } \\
& 2 \text { etendus vä. } \\
& \text { performance QUES } \\
& \text { 'performance?' }
\end{aligned}
$$

Prosodically, uvitav is latched to the interrogative clause. Even though it may carry a certain amount of stress and start in high pitch, it never displays a final contour other than in turn-final cases. Characteristically to particularized items, uvitav may be considerably reduced phonologically, as shown in Example (30).

Interactionally and grammatically, the interrogative clause following, preceding, or surrounding uvitav is profiled and independent. Uvitav-prefaced questions initiate topically tied new sequences, which introduce a new aspect on 
what has just been talked about. While they also display epistemic uncertainty about the availability of the response, their use displays the speaker's understanding of where and how the turn is appearing in the sequence of conversational events and what its status is in regard to the assumed knowledge state of the recipient.

\section{Conclusion}

Based on conversational data, this study shows that a number of interrogative clauses that have been analyzed as subordinate complements are treated as profiled by the participants. The interrogative clauses discussed above display clear features of being independent, while the 'main clauses' behave as particles that structure conversation and express epistemic matters. To demonstrate this, interactional, syntactic and prosodic features were discussed.

Interactionally, recipients of the turns involving ütle/öelge, räägi, (ei) tea, uvitav + interrogative clause treat them as questions by answering the interrogative clause. Syntactically, the interrogative clauses may involve inversion and the turnfinal question particle $v \ddot{a} / v e$, which is impossible in dependent clauses in Estonian. Content-wise, the relevant information is provided in the interrogative clause. Furthermore, ütle/öelge and rä̈gi do not necessarily appear adjacent to the interrogative clause. There is thus hardly any grammatical reason for considering the following interrogative clauses subordinate complements. Prosodically, the CTP clauses were often produced as enclitics incorporated into a larger intonation unit, without carrying the most prominent stress themselves. The paper suggests a different analysis for the clauses presented in the introduction and discussed through the paper.

\section{(Epistemic) particle Independent clause}

Ütle

Räägi

Ei tea mis ma tegema pean 'what do I have to do?' kuidas sul läks täna 'how did it go today?' mis kellast doctor Laane vastu võtab 'when will doctor Laane be seeing patients?' miks ma talle meeldin 'why does she like me?'

Uvitav

Thus, the notion of subordination, insofar as it is a relationship between two clauses, is not relevant in the current patterns. Nevertheless the analysis suggests that even turn-beginnings consisting of fully fledged clauses, such as oskad sa öelda 'can you tell me' or ega te ei tea 'I suppose you don't know', could be treated as action-projection formats. Instead of seeing the relationship between these formats 
and the following interrogative clauses as a case of morphosyntactic subordination or a reflection of hierarchical cognitive profiling, we might have to analyze it in terms of temporality. Formats like these orient the speakers in the real-time sequencing of actions and deal with interpersonal face needs. What kind of advantages are achieved by early action-projection in the turn and by taking care of interpersonal relations before the main action is produced could be a subject of another study.

As was shown above, all of the focused items are devices of question formation in Estonian. As turn- and utterance-initial particles with particular prosodic features (non-final contours), they partake in projection in interaction. One of the functions of at least ütle, räägi, and (ei) tea is to project that a question is coming up and thus define early on in the turn that it is going to be about information request. While showing the action type of the turn and thus even what the next relevant action should be, they do not yet do the action and do not reveal anything about its content. Projection in itself helps the speakers to coordinate their actions.

Designing the questions not only by producing an interrogative but also by adding a pragmatic particle enables the speaker to define and display the nature and sequential placement of the contribution for current participants. The question prefaces discussed above deal with the action type of the turn and the positioning of it within the whole interactive sequence. Especially the particles ütle, rä̈gi, and uvitav display to the participant(s) the understanding of where the upcoming utterance belongs in a sequence of actions. Topic-initiations, including reasons for the call can be formatted with ütle and räägi, while continuations are formulated with uvitav.

All of the devices described here also do intersubjective work by suggesting the level of certainty of recipient knowledge. The imperatives display strong assumption that the recipient knows the answer, also turn-finally, while ei tea and uvitav show that the availability of relevant knowledge among the participants is uncertain. They contextualize the interrogative clauses in terms of the respective knowledge states of the participants and ease the contextual pressure for the recipient to produce an answer as the next turn. These formats that may indeed look like prototypical subordinating constructions, when written down, are actually combinations of interrogative clauses and particles specialized in dealing with sequential and interpersonal matters for current participants in conversation. 


\section{References}

Auer, Peter. 1996. "The pre-front field in spoken German and its relevance as a grammaticalization position." Pragmatics 6(3): 295-322.

Auer, Peter. 2005. "Projection in interaction and projection in grammar." Text 25(1): 7-36.

Brinton, Laurel J. 2001. "From matrix clause to pragmatic marker: the history of look-forms." Journal of Historical Pragmatics 2(2): 177-199.

Bybee, Joan and Hopper, Paul. 2001. "Introduction to frequency and the emergence of linguistic structure." In Frequency and the Emergence of Linguistic Structure [Typological Studies in Language 45], Joan Bybee and Paul Hopper (eds), 1-24. Amsterdam, Philadelphia: John Benjamins.

Couper-Kuhlen, Elizabeth. 2001. "Interactional prosody: High onsets in reason-for-the-call turns." Language in Society 30(1): 29-53.

Couper-Kuhlen, Elizabeth and Thompson, Sandra. 2008. "On assessing situations and events in conversation: 'extraposition' and its relatives”. Discourse Studies 10(4): 443-467.

Curl, Traci and Drew, Paul. 2008. "Contingency and action: A comparison of two forms of requesting." Research on Language and Social Interaction 41(2): 129-153.

Englebretson, Robert. 2003. Searching for structure: The problem of complementation in colloquial Indonesian conversation. Amsterdam, Philadelphia: John Benjamins.

Erelt, Mati. 1990. "Kõneleja ja kuulaja kaudse väljendamise võimalusi eesti keeles." Keel ja Kirjandus 38(1): 35-39.

Erelt, Mati, Kasik, Reet, Metslang, Helle, Rajandi, Heino, Ross, Kristiina, Saari, Henn, Tael, Kaja and Vare, Silvi. 1993, 1995. Eesti keele grammatika I-II (Estonian grammar I-II). Tallinn: Eesti Teaduste Akadeemia Eesti Keele Instituut.

Günthner, Susanne. 2008. "Projective constructions in German interactions - an analysis of pseudo-clefts, N-be-that-constructions and extraposition." Talk given at LISO, Santa Barbara, March 7th

Hakulinen, Auli, Keevallik Eriksson, Leelo and Lindström, Jan. 2003. "Kuule, kule, hördu - projicerande praktiker i finska, estniska och svenska samtal." In Grammatik och Samtal: Studier till minne av Mats Eriksson [Skrifter utgivna av institutionen för nordiska språk vid Uppsala universitet 63], Bengt Nordberg, Leelo Keevallik Eriksson, Kerstin Thelander and Mats Thelander (eds), 199-218. Uppsala: Uppsala universitet.

Hopper, Paul. 1987. "Emergent grammar." Berkeley Linguistics Society: Papers of the Thirteenth Annual Meeting: 139-157.

Hopper, Paul. 1998. Emergent grammar. In The New Psychology of Language: cognitive and functional approaches to language structure, Michael Tomasello (ed.), 155-175. Mahwah NJ: Lawrence Erlbaum.

Hopper, Paul and Thompson, Sandra A. 2008. "Projectability and Clause Combining in Interaction." In Crosslinguistic Studies of Clause Combining: The Multifunctionality of Conjunctions, Ritva Laury (ed.), 99-124. Amsterdam, Philadelphia: John Benjamins.

Keevallik, Leelo. 1999. "The use and abuse of singular and plural address forms in Estonian." International Journal of the Sociology of Language 139: 125-144.

Keevallik, Leelo. 2003. From interaction to grammar: Estonian finite verb forms in conversation [Acta Universitatis Upsaliensis. Studia Uralica Upsaliensia 34]. Uppsala: Uppsala university.

Keevallik, Leelo. 2006. "From discourse pattern to epistemic marker: Estonian ei tea 'don't know"” Nordic Journal of Linguistics 29(2): 173-200. 
Keevallik, Leelo. 2010. "Hinnangu grammatikast." [On the grammar of assessments]. In Keele Rajad Pühendusteos professor Helle Metslangi 60. sünnipäevaks, Ilona Tragel (ed.) Eesti ja soome-ugri keeleteaduse ajakiri 2: 147-161.

Langacker, Ronald W. 1991. Foundations of Cognitive Grammar. Vol II: Descriptive Applications. Stanford: Stanford University Press.

Laury, Ritva. 2006. “On Subordination, Finnish-Style: Questioning the Category of Finite Clausal Complements in Spoken Finnish." SKY Journal of Linguistics 19: 310-321.

Lindholm, Camilla and Lindström, Jan. 2003. "Får jag fråga? Frågeramar i institutionell interaktion." Språk \& Stil NF 13: 35-64.

Lindström, Jan. 2002. "Från satsschema till turschema? Förfältet i fokus." Språk \& Stil NF 11:25-80.

Matthiessen, Christian and Thompson, Sandra A. 1988. "The structure of discourse and 'subordination."' In Clause combining in grammar and discourse, John Haiman and Sandra A. Thompson (eds), 275-329. Amsterdam, Philadelphia: John Benjamins.

Payne, Thomas E. 1997. Describing Morphosyntax: A Guide for Field Linguists. Cambridge: Cambridge University Press.

Sacks, Harvey, Schegloff, Emanuel A. and Jefferson, Gail. 1974. "A simplest systematics for the organization of turn-taking for conversation." Language 50(4): 696-735.

Schegloff, Emanuel A. 1980. "Preliminaries to preliminaries: "Can I ask you a question?'”' Sociological Inquiry 50(3-4): 104-152.

Schegloff, Emanuel A. 1996. "Turn organization: One intersection of grammar and interaction." In Interaction and Grammar, Elinor Ochs, Emanuel A. Schegloff and Sandra A. Thompson (eds), 52-133. Cambridge: Cambridge University Press.

Thompson, Sandra A. 2002. “"Object complements” and conversation. Towards a realistic account." Studies in Language 26(1): 125-164.

Thompson, Sandra A. and Mulac, Anthony. 1991. "A Quantitative perspective on the grammaticalization of epistemic parentheticals in English." In Approaches to Grammaticalization, Vol. II. Focus on Types of Grammatical Markers [Typological Studies in Language 19], Elizabeth C. Traugott and Bernd Heine (eds), 313-339. Amsterdam, Philadelphia: John Benjamins.

Tulviste, Tiia, Mizera, Luule, de Geer, Boel and Tryggvason, Marja-Terttu. 2002. "Regulatory comments as tools of family socialization: A comparison of Estonian, Swedish and Finnish mealtime interaction." Language in Society 5 (31): 655-678.

Waltereit, Richard. 2002. "Imperatives, interruption in conversation and the rise of discourse particles: A study of Italian guarda." Linguistics 40(5): 987-1010.

\section{Transcription and glossing conventions}

$\begin{array}{ll}\text { underlining } & \begin{array}{l}\text { emphasis } \\ \text { truncation } \\ \text { overlapped talk }\end{array} \\ = & \text { latching of turns } \\ <= & \text { next unit initiated hastily } \\ (0.5) & \text { pause length in tenths of a second } \\ (.) & \text { micropause } \\ : & \text { lengthening of a sound }\end{array}$

(C) 2011. John Benjamins Publishing Company

All rights reserved 


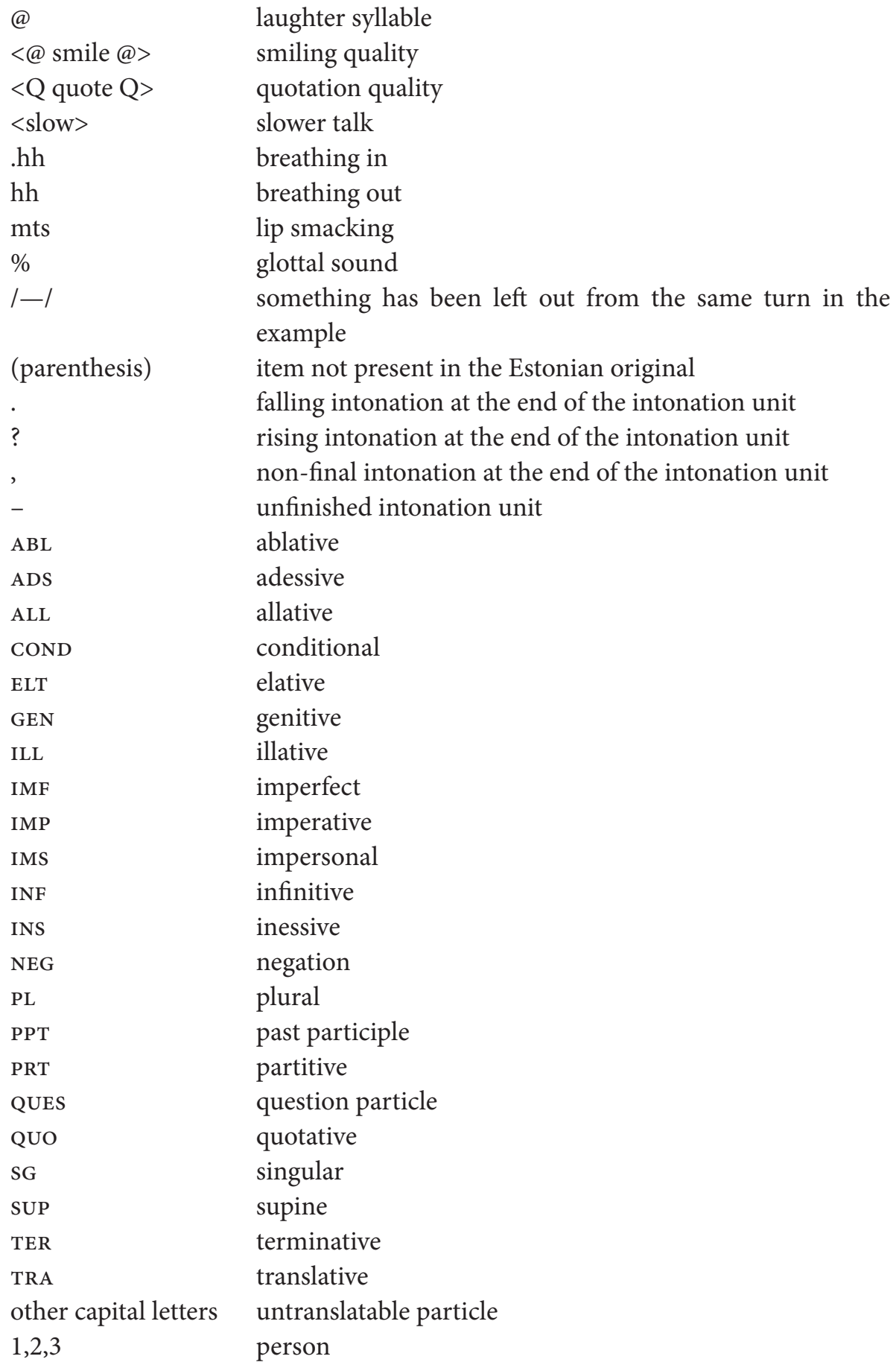

